\title{
KESALAHAN BERBAHASA PADA SURAT DINAS SMA NEGERI 9 KOTA JAMBI
}

\author{
Firman Tara ${ }^{1}$, Desri Karlinda ${ }^{2}$ \\ Program Studi Pendidikan Bahasa dan Sastra Indonesia, \\ Fakultas Keguruan dan Ilmu Pendidikan, Universitas Batanghari, \\ Jambi \\ karlindadesri@gmail.com \\ firmantara14@gmail.com
}

\begin{abstract}
This research aims at describing language errors in writing letter numbers, mailing letter, opening paragraph, and closing paragraph of official letters of SMA Negeri 9 Jambi City year of 2019. This research is a qualitative descriptive. The technique used in collecting data are observation and documentation. The results of the analysis show that the errors in writing letter numbers are the use of colons and slashes which are preceded and followed by a space. Errors in writing mailing letter is indicated in the use of kepada which indicates language redundancy; the use of a colon (:) which should be replaced by a period (.); the use of punctuation marks (.) at the end of the mailing address; and the use of bold letters in the mailing address. Written errors in the opening paragraph of the letter are the writing of the opening greeting Dengan hormat in the beginning of the paragraph that should be included in the first sentence of the letter opening. Written errors in the closing paragraphs of letters are the incomplete closing sentences of the letter which should have been mentioned earlier, written behind the word demikianlah; and errors in the use of preposition di.
\end{abstract}

Keywords: analysis, language errors, official letter

${ }^{1}$ Dosen Program Studi Pendidikan Bahasa dan Sastra Indonesia, Fakultas Keguruan dan Ilmu Pendidikan, Universitas Batanghari, Jambi

2 Mahasiswa Program Studi Pendidikan Bahasa dan Sastra Indonesia, Fakultas Keguruan dan Ilmu Pendidikan, Universitas Batanghari, Jambi 


\section{PENDAHULUAN}

Bahasa memegang peranan yang sangat penting bagi manusia. Dengan bahasa manusia dapat berinteraksi sosial, berkomunikasi, dan dapat bekerja sama dengan orang lain karena pada hakikatnya bahasa adalah alat komunikasi. Manusia tanpa adanya bahasa tidak akan dapat berkomunikasi dengan baik dan sempurna dalam menyampaikan pesan yang ingin disampaikan.

Komunikasi adalah satu tindakan yang mendorong untuk mengungkapkan ide dan gagasan yang ingin disampaikan oleh pemberi pesan. Penggunaan bahasa dalam komunikasi terdiri dari dua saluran yakni, ragam lisan dan ragam tulis (Moeliono, 1993: 7). Ragam lisan adalah ragam bahasa yang diungkapkan melalui media lisan yang terikat oleh kondisi, ruang dan waktu sehingga situasi saat pengungkapan dapat membantu pemahaman pendengar, sedangkan ragam tulis adalah ragam bahasa yang dipergunakan melalui media tulis, yang tidak terikat oleh ruang dan waktu.

Penggunaan media tulis bisa dilakukan pada saat penulisan surat. Surat merupakan suatu sarana komunikasi antara dua pihak secara tertulis untuk menyampaikan informasi. Informasi dapat berupa pemberitahuan, pernyataan, laporan usulan, dan sebagainya. Surat sebagai sarana berkomunikasi tertulis, paling tidak melibatkan dua pihak yaitu pengirim surat dan penerima surat.

Tujuan utama orang menulis surat ialah untuk menginformasikan dan mengkomunikasikan suatu pemikiran dan gagasan kepada orang lain dengan maksud tertentu. Surat menjadi salah satu sarana komunikasi yang memiliki kelebihan dibandingkan dengan sarana komunikasi lisan. Kelebihan itu di antaranya surat yang diberikan kepada pembaca akan dapat dibaca berulangulang, apabila pembaca tidak dapat memahami dengan isi informasi yang diberikan dalam surat tersebut.

Berdasarkan isinya, surat dapat dibedakan menjadi tiga jenis, yaitu surat pribadi, surat dinas/resmi, dan surat niaga/dagang. Surat dinas merupakan surat-surat resmi yang di dalamnya menyangkut berbagai hal tentang kedinasan, misalnya: pengangkatan pegawai, kenaikan pangkat, kenaikan gaji, perpindahan pegawai, dan keputusan pemberhentian pegawai (Darmawati, 2007: 1). Surat dinas ini sering digunakan dalam instansi pemerintah maupun instansi pendidikan.

Salah satu instansi pendidikan yang menggunakan surat dinas sebagai alat komunikasi adalah Sekolah Menengah Atas (SMA) Negeri 9 Kota Jambi. Dalam suatu instansi, khususnya SMA Negeri 9 Kota Jambi banyak melaksankan kegiatan yang melibatkan banyak pihak seperti rapat guru, rapat kegiatan sekolah, rapat ujian semester dan lain-lain. Oleh karena itu, untuk memperlancar pelaksanaan kegiatan tersebut, diperlukan media komunikasi yaitu surat guna menyampaikan informasi-informasi seperti pemberitahuan, perintah, permintaan, undangan, tugas, maupun teguran kepada pihak-pihak yang bersangkutan.

Surat-surat yang dikeluarkan oleh instansi-instansi pendidikan sudah seharusnya menggunakan bahasa dan tata cara penulisan yang baku sebagaimana yang tertulis dalam pasal 33 ayat 1 Undang-Undang 24 Tahun 2009 yang berbunyi "Bahasa Indonesia Wajib digunakan dalam komunikasi resmi di lingkungan kerja pemerintah dan swasta". Komunikasi yang dimaksud 
adalah komunikasi jarak jauh maupun jarak dekat.

Penggunaan bahasa yang baku dan tata cara penulisan yang baku akan mempermudah pembaca dalam memahami pesan yang disampaikan serta akan menghindari dari salah penafsiran pada isi surat. Dengan demikian, kegaiatan dalam berkomunikasi akan berjalan dengan lancar. Sejalan dengan hal tersebut, Semi (2008: 9) berpendapat "Apabila surat yang ditulis tidak beres, baik bentuk maupun bahasanya, tentu surat itu tidak mendapat sambutan yang baik. Sebaliknya, bila surat yang kita tulis itu rapi dan memenuhi ketentuan menulis surat yang baik dan benar, tentu saja surat itu mendapat sambutan yang baik."

Pada kenyataannya, penulisan surat dinas tidaklah mudah. Apalagi bagi pegawai bagian tata usaha sekolah, yang rata-rata pendidikannya tidak berlatarbelakang pendidikan bahasa Indonesia sehingga pemahaman akan bahasa maupun tata cara penulisan surat yang baku masih kurang. Selain itu, penggunaan bahasa ibu dalam lingkungan sekolah secara tidak langsung juga mempengaruhi penggunaan bahasa Indonesia. Hal tersebut senada dengan pendapat Rofii (2015) bahwa bahasa pertama (bahasa Ibu) dapat mempengaruhi penggunaan bahasa kedua. Memang pada dasarnya penggunaan bahasa ibu tidak dilarang, tetapi sudah menjadi kewajiban pegawai pendidikan untuk menggunakan bahasa Indonesia yang baik dan benar.

Berdasarkan pengamatan awal, terhadap surat dinas yang dikeluarkan oleh SMA Negeri 9 Kota Jambi diketahui masih banyak terdapat kesalahan, baik dari segi bahasa maupun cara penulisannya. Banyaknya penyimpangan yang terjadi akan menjadikan informasi surat sulit dipahami. Misalnya salah satu surat resmi perihal Pengarahan dan Pembinaan.. Kesalahan pertama yang terjadi pada kesalahan nomor surat yaitu Nomor: 800 /229/ SMA 9 /LL/ 2019, kesalahan penulisan nomor surat itu adalah setelah huruf dan angka menggunakan spasi hal itulah yang menyebabkan salah. Karena menurut aturan yang berlaku, tanda garis miring tidak didahului dan diikuti spasi, sehingga penulisan yang benar yaitu Nomor: $\quad$ 800/229/SMA9/LL/2019.

Kesalahan kedua pada penulisan alamat surat yaitu Kepada Yth: K.a Dinas Pendidikan Provinsi Jambi, kesalahan penulisan alamat surat itu adalah penggunaan kata Kepada yang tidak seharusnya ditulis, sebab siapapun sudah mengetahui bahwa alamat yang ditulis itu merupakan alamat yang dituju dan kesalahan singkatan $K . a$ seharusnya tidak disingkat melainkan ditulis langsung yaitu Kepala. Jadi penulisan yang benar seharunya adalah Yth. Kepala Dinas Pendidikan Provindi Jambi. Berdasarkan paparan di atas, maka penelitian ini penting untuk dilaksanakan.

Berdasarkan latar belakang yang telah dikemukakan, perlu dilakukan pengidentifikasian masalah yang terkait dengan topik yang akan dibahas. Kesalahan bahasa dalam surat resmi dapat terjadi pada (1) format surat, (2) kesalahan penulisan kepala surat, (3) kesalahan penulisan nomor surat, (4) kesalahan penulisan lampiran, (5) kesalahan penulisan hal surat, (6) kesalahan penulisan tanggal surat, (7) kesalahan penulisan alamat surat, (8) kesalahan penulisaan salam pembuka, (9) kesalahan penulisan paragraf pembuka, (10) kesalahan penulisan paragraf penutup, (11) kesalahan penulisan salam penutup, dan (12) kesalahan penulisan tembusan Rahmadi (2017: 183-195). 
Berdasarkan identifikasi masalah, diketahui bahwa permasalahan yang ditemukan terlalu luas. Dengan demikian, penelitian ini hanya dibatasi pada beberap aspek, sebagai berikut.

1. Kesalahan bahasa penulisan nomor surat pada surat dinas SMA Negeri 9 Kota Jambi tahun 2019.

2. Kesalahan bahasa penulisan alamat surat pada surat dinas SMA Negeri 9 Kota Jambi tahun 2019.

3. Kesalahan bahasa penulisan paragraf pembuka pada surat dinas SMA Negeri 9 Kota Jambi tahun 2019.

4. Kesalahan bahasa penulisan paragraf penutup pada surat dinas SMA Negeri 9 Kota Jambi tahun 2019.

Adapun pertanyaan penelitian dalam penelitian ini, sebagai berikut.

1. Bagaimanakah kesalahan bahasa penulisan nomor surat pada surat dinas SMA Negeri 9 Kota Jambi tahun 2019?

2. Bagaimanakah kesalahan bahasa penulisan alamat surat pada surat dinas SMA Negeri 9 Kota Jambi tahun 2019?

3. Bagaimanakah kesalahan bahasa penulisan paragraf pembuka pada surat dinas SMA Negeri 9 Kota Jambi tahun 2019?

4. Bagaimanakah kesalahan bahasa penulisan paragraf penutup pada surat dinas SMA Negeri 9 Kota Jambi tahun 2019?

Berdasarkan fokus dan pertanyaan penelitian tersebut, maka dapat ditentukan tujuan yang hendak dicapai dalam penelitian ini, sebagai berikut.

1. Mendeskripsikan kesalahan bahasa penulisan nomor surat pada surat dinas SMA Negeri 9 Kota Jambi tahun 2019.

2. Mendeskripsikan kesalahan bahasa penulisan alamat surat pada surat dinas SMA Negeri 9 Kota Jambi tahun 2019.

3. Mendeskripsikan kesalahan bahasa penulisan paragraf pembuka pada surat dinas SMA Negeri 9 Kota Jambi tahun 2019.

4. Mendeskripsikan kesalahan bahasa penulisan paragraf penutup pada surat dinas SMA Negeri 9 Kota Jambi tahun 2019.

\section{Kajian Teoretis}

Bahasa adalah suatu sistem lambang berupa bunyi, bersifat arbitrer, digunakan oleh suatu masyarakat tutur untuk bekerja sama, berkomunikasi, dan mengidentifikasi diri (Chaer, 2006: 1). Fungsi dari bahasa itu pada umumnya yaitu sebagai alat komunikasi atau alat perhubungan antar anggota-anggota masyarakat; suatu komunikasi yang diadakan dengan mempergunakan bunyi yang dihasilkan oleh alat-ucap manusia (Keraf, 1984: 17). Fungsi bahasa yang terutama adalah sebagai alat untuk bekerja sama atau berkomunikasi di dalam kehidupan manusia bermasyarakat. Rofii dan Hasibuan (2019:17) mengatakan bahwa Fungsi bahasa yang paling mendasar ialah sebagai alat komunikasi. Bahasa digunakan masyarakat sebagai alat pergaulan antarsesama dan alat untuk menyampaikan sebuah pemikiran. Bahasa Indonesia sendiri, yang mempunyai kedudukan sebagai bahasa nasional dan bahasa resmi negara di tengah-tengah berbagai macam bahasa daerah (Chaer, 2006: 2).

Penggunaan bahasa dalam komunikasi terdiri dari dua saluran yakni, ragam lisan dan ragam tulis (Moeliono, 1993: 7). Ragam lisan adalah ragam bahasa yang diungkapkan melalui media lisan yang terikat oleh kondisi, ruang dan waktu sehingga situasi saat 
pengungkapan dapat membantu pemahaman pendengar. Ragam tulis adalah ragam bahasa yang dipergunakan melalui media tulis, yang tidak terikat oleh ruang dan waktu. Berdasarkan media yang digunakan ragam bahasa dibedakan atas (1) ragam bahasa lisan: berpidato, berdiskusi, bertelpon, dan (2) ragam bahasa tulis (Widjono, 2015: 31).

Surat adalah sarana untuk menyampaikan informasi secara tertulis dari pihak yang satu ke pihak yang lain, informasi itu dapat berupa pemberitahuan, pernyataan, pertanyaan, sikap dan lain-lain (Semi, 2008: 1). Surat dinas (resmi) adalah surat yang menyangkut kedinasan yang dikeluarkan oleh lembaga resmi seperti jawatan, kantor, organisasi, dan dikirimkan kepada siapa saja, baik perorangan maupun kantor, organisasi, atau jawatan lainnya (Semi, 2008: 1).

Fungsi utama surat pada umunya yaitu untuk menyampaikan pesan secara dua arah, baik dari pemberi pesan dan penerima pesan yang ingin disampaikan meliputi penyampaian informasi, gagasan, pemberitahuan, dan lainnya kepada penerima surat. Di samping itu surat memiliki fungsi sebagai dokumentasi tertulis, alat pengingat, dan bukti tertulis (Darmawati, 2007: 2).

Bahasa surat digunakan sebagai bagian dari inti surat. Bahasa yang digunakan hendaklah harus mematuhi aturan kaidah kebahasaan penulisan surat yang benar. Bahasa surat merupakan bahasa tulis, maka aturan yang menyangkut tentang bahasa tulis harus diperhatikan, misalnya, mengenai paragraf, pemakaian kalimat topik, ejaan, dan lain-lain (Semi, 2008: 83).

Bentuk atau format surat dinas adalah sebagai berikut: 1) kop surat, 2) nomor surat, 3) hal surat, 4) tempat dan tanggal pembuatan surat, 5) alamat surat,
6) salam pembuka, 7) kalimat pembuka surat, 8) isi surat, 9) kalimat penutup surat, 10) salam penutup, 11) tanda tangan, 12) nama pengirim surat, dan 13) jabatan pengirim surat. Berikut merupakan penjelasan dari bagian-bagian surat (Darmawati, 2007: 3).

Kesalahan berbahasa adalah penggunaan bahasa yang menyimpang dari kaidah bahasa yang berlaku dalam bahasa itu (Rofii, 2015). Analisis kesalahan berbahasa adalah suatu proses kerja yang digunakan oleh guru dan peneliti bahasa dengan langkah-langkah pengumpulan data, pengidentifikasian kesalahan yang terdapat di dalam data, penjelasan kesalahan tersebut, pengklasifikasian kesalahan itu berdasarkan penyebabnya, serta pengevaluasian taraf keseriusan kesalahan itu (Rahmadi, 2017:201).

Kesalahan bahasa dalam surat resmi dapat terjadi pada (1) format surat, (2) kesalahan penulisan kepala surat, (3) kesalahan penulisan nomor surat, (4) kesalahan penulisan lampiran, (5) kesalahan penulisan hal surat, (6) kesalahan penulisan tanggal surat, (7) kesalahan penulisan alamat surat, (8) kesalahan penulisaan salam pembuka, (9) kesalahan penulisan paragraf pembuka, (10) kesalahan penulisan paragraf penutup, (11) kesalahan penulisan salam penutup, dan (12) kesalahan penulisan tembusan (Rahmadi, 2017: 183).

\section{METODE PENELITIAN}

Jenis penelitian ini adalah penelitian deskritif dengan pendekatan kualitatif yang berkaitan dengan kajian bahasa. Dalam hal ini pendekatan kualitatif adalah "Suatu pendekatan yang juga disebut pendekatan investigasi karena biasanya peneliti mengumpulkan data dengan cara bertatap muka langsung dan berinteraksi dengan orang-orang di 
tempat penelitian (McMillan \& Schumacher, 2003: 73).”

Jenis penelitian kualitatif merupakan cara yang digunakan dalam penelitian untuk memecahkan masalah dengan mendeskripsikan data-data berdasarkan fakta yang ada. Menurut Denzim dan Lincoln (dalam Moleong 2012: 42) yang dimaksud dengan penelitian kualitatif adalah "Penelitian yang menggunakan latar alamiah, dengan maksud menafsirkan fenomena yang terjadi dan dilakukan dengan jalan melibatkan berbagai metode yang ada."

Tempat penelitian ini dilakukan di Kota Jambi yaitu SMA Negeri 9 Kota Jambi Tahun 2019. Penelitian ini dimulai dari tanggal 13 November 2019 sampai dengan Agustus 2020 sesuai dikeluarkan SK bimbingan Nomor 256 Tahun 2019.

Adapun teknik pengumpulan data yang digunakan dalam penelitian ini yaitu teknik observasi dan dokumentasi. Data yang dikumpulkan berupa kata-kata, gambar, dan bukan angka-angka. Dengan demikian, laporan penelitian akan berisi kutipan-kutipan data untuk memberi gambaran penyajian laporan tersebut. Data tersebut mungkin berasal dari naskah wawancara, catatan lapangan, foto, videotape, dokumen pribadi, catatan atau memo, dan dokumen resmi lainnya (Moleong, 2012: 42).

Analisis data adalah proses mencari dan menyusun secara sistematis data yang diperoleh dari hasil wawancara, catatan lapangan, dan bahanbahan lain, sehingga dapat mudah difahami (Sugiyono, 2016: 244). Dengan kata lain analisis data salah satu cara kegiatan analisis data yang ada berdasarkan aturan yang telah ditentukan.

\section{HASIL DAN PEMBAHASAN}

penelitian yang telah dilakukan

ditemukan beberapa hal terkait dengan kesalahan berbahasa pada penulisan surat dinas SMA Negeri 9 Kota Jambi tahun 2019, sebagai berikut.

\section{a. Kesalahan Penulisan pada Nomor Surat}

Nomor surat ini diperlukan karena dengan adanya nomor surat ini dapat dengan mudah mengatur penyimpanannya sebagai arsip, menemukan kembali bila diperlukan, dan mengetahui jumlah surat yang keluar (Semi, 2008: 52). Kesalahan yang ditemukan pada penulisan nomor surat dinas SMA Negeri 9 Kota Jambi tahun 2019 adalah sebagai berikut.

1) Nomor: $1.1 .19 / 800 / 048 /$ SMA 9/ LL/2019

2) Nomor: 1.1.19/800/048/ SMA 9/LL/2019

3) Nomor: 1.1.19/800/ 048 / SMA 9/LL/2019

4) No:800/ 077/SMA9/LL/2019

5) No: 800/139/SMA9/LL/2019 Berdasarkan data tersebut diketahui kesalahan penulisan pada nomor surat dinas dinas SMA Negeri 9 Kota Jambi tahun 2019 sebagai berikut.

1. Adanya tanda baca garis miring yang didahului dan diikuti oleh spasi. Menurut aturan yang berlaku, penulisan nomor surat yang benar tidak perlu diberi spasi. Pemberian spasi membuka peluang bagi orang lain untuk mengubahnya (Darmawati, 2007: 5).

2. Pada penulisan kata No yang boleh disingkat tetapi harus menggunakan tanda baca titik setalah penulisan $N o$. Karena ketika penulisannya disingkat harus menggunakan tanda baca titik setelahnya menjadi No. (Soedjito \& Solchan, 2013: 42).

Sehingga penulisan nomor surat dinas yang benar adalah: 
1) Nomor:1.1.19/800/048/SMA9/LL $/ 2019$

2) Nomor:1.1.19/800/048/SMA9/LL /2019

3) Nomor:1.1.19/800/048/SMA9/LL 12019

4) No.:800/077/SMA9/LL/2019

5) No.:800/139/SMA9/LL/2019

\section{b. Kesalahan Penulisan pada Alamat} Surat

Alamat surat berisikan nama lengkap dan identitas atau alamat dari pihak yang terkirim. Alamat fungsinya sebagai penunjuk dalam menyampaikan surat kepada orang yang berhak menerimanya. Oleh karena itu, penulisan alamat surat haruslah lengkap dan jelas (Kosasih, 2012: 100). Kesalahan yang ditemukan pada penulisan alamat surat dinas SMA Negeri 9 Kota Jambi tahun 2019 sebagai berikut.

\section{1) Kepada}

Yth : Direktur PT.

Perusahaan Listrik Negara (PLN) Jambi

di - Jambi.
2) Kepada
Yth
Provinsi Jambi Ka. Dinas Pendidikan
di -
Jambi.
3) Kepada Yth.
KAPOLRESTA Jambi
Di,
Jambi
Yth : Kepala BKD PROVINSI
Kepada
JAMBI di -
Jambi.
Berdasarkan data tersebut
diketahui kesalahan penulisan pada
alamat surat dinas SMA Negeri 9 Kota
Jambi tahun 2019 sebagai berikut.

1. Penggunaan kata "kepada" yang tidak perlu ditulis karena siapapun sudah mengetahui bahwa alamat surat yang ditulis itu adalah alamat yang dituju (Rahmadi, 2017: 189).

2. Penggunaan kata sapaan tidak perlu ditulis di depan gelar, pangkat, dan jabatan. Kata sapaan digunakan jika diikuti langsung oleh nama orang yang dituju (Rahmadi, 2017: 189).

3. Kesalahan pada penggunaan huruf tebal pada alamat surat yang seharusnya ditulis tanpa menggunakan huruf tebal karena huruf tebal digunakan sebagai penegas bagian tulisan (Rahmadi, 2017: 33), sedangkan alamat surat bukan merupakan bagian tulisan yang perlu ditegaskan.

4. Nama kota, nama jabatan, nama tempat tidak perlu ditulis kapital seluruhnya, tetapi awalnya saja yang menggunakan huruf kapital (Rahmadi, 2017: 25).

5. Kesalahan pada penggunaan tanda baca titik dua (:) yang seharusnya diganti dengan tanda titik (.), karena tanda baca titik dua (:) dipakai pada akhir suatu pernyataan lengkap yang diikuti pemerincian atau penjelasan (Rahmadi, 2017: 59). Sedangkan alamat surat tidak menyatakan perincian maka tidak diperlukan menggunakan tanda baca titik dua. Singkatan Yth. juga seharusnya menggunakan tanda titik bukan dengan tanda titik dua, karena singkatan yang terdiri atas tiga huruf atau lebih diikuti dengan tanda titik (Rahmadi, 2017: 44).

6. Kesalahan pada penulisan kata $d i$ yang tidak perlu ditulis karena nama kota tidak didahului kata depan $d i$, tidak ditulisakan dengan huruf kapital semua, tidak perlu digaris bawahi, dan tidak bertitik akhir atau 
tanda baca lainnya (Soedjito \& Solchan, 2013: 46).

7. Kesalahan pada singkata $K a$. yang seharusnya ditulis langsung menjadi Kepala tidak perlu disingkat, karena penulisan alamat surat hendaknya ditulis dengan jelas, singkat, dan lengkap (Rahmadi, 2017: 189).

Sehingga penulisan alamat surat yang benar adalah

1) Yth. Direktur PT. Perusahaan Listrik Negara (PLN) Jambi

2) Yth. Kepala Dinas Pendidikan Provinsi Jambi

3) Yth. Kapolresta Jambi

4) Yth. Kepala BKD Provinsi Jambi

\section{c. Kesalahan Penulisan pada Paragraf Pembuka}

Paragraf pembuka sesuai dengan namanya adalah untuk menyampaikan informasi pengantar atau pendahuluan (Semi, 2008:60). Kesalahan penulisan paragraf pembuka surat dinas SMA Negeri 9 Kota Jambi Tahun 2019 sebagai berikut.

1) Dengan hormat, dengan ini kami sampaikan bahwa SMA Negeri 9 Kota Jambi akan mengadakan Ujian Sekolah Berbasis Komputer (USBK) tahun 2019 yang akan dilaksanakan mulai tanggal 15 s.d 28 Maret 2019 dengan menggunakan komputer, oleh sebab itu kami mohon kepada bapak agar tidak pemadaman listrik untuk wilayah Payo Selincah khususnya wilayah SMA Negeri 9 Kota Jambi.

2) Sehubungan dengan adanya surat dari Kepolisian Negara Republik Indonesia Resor Kota jambi Nomor: B/741/III/2019/Reskrim tanggal 26 Maret 2019, perihal permintaan dokumen yang terkait dengan dugaan tindak pidana korupsi penyalahgunaan dana BOS SMA N 9 Kota Jambi Tahun Anggaran
2017/2018, dengan ini kami dari pihak sekolah ingin memberikan keterangan terkait dengan permasalahan tersebut.

3) Sehubungan dengan adanya terjadi konsleting kabel PLN menuju jalur SMAN 9 Kota Jambi.

Berdasarkan data tersebut diketahui kesalahan penulisan pada kesalahan penulisan paragraf pembuka surat dinas SMA Negeri 9 Kota Jambi Tahun 2019 berikut.

1. Kesalahan pada penulisan salam pembuka Dengan hormat, diawal paragraf yang seharusnya dimasukkan ke dalam kalimat pertama pembuka surat. Karena salam pembuka Dengan hormat, jika tidak digunakan secara sendirisendiri, sebaiknya dimasukkan ke dalam kalimat pertama pembuka surat (Soedjito \& Solchan: 2008: 52).

2. Kesalahan pada penulisan dengan ini kami sampaikan bahwa yang seharusnya diganti dengan ini kami beri tahukan bahwa. Karena surat ini merupakan suatu pemberitahuan. Untuk surat-surat yang berisi suatu pemberitahuan dipergunakan kalimat pembuka Dengan ini kami beri tahukan bahwa...(Soedjito\&Solchan: 2008: 53).

Sehingga penulisan paragraf pembuka yang benar sebagai berikut.

1) Kami beri tahukan dengan hormat bahwa SMA Negeri 9 Kota Jambi akan mengadakan Ujian Sekolah Berbasis Komputer (USBK) tahun 2019 yang akan dilaksanakan mulai tanggal 15 s.d 28 Maret 2019 dengan menggunakan komputer, oleh sebab itu kami mohon kepada bapak agar tidak pemadaman listrik untuk wilayah Payo Selincah khususnya wilayah SMA Negeri 9 Kota Jambi. 
2) Dengan ini kami beri tahukan sehubungan adanya surat dari Kepolisian Negara Republik Indonesia Resor Kota jambi Nomor: B/741/III/2019/Reskrim tanggal 26 Maret 2019, perihal permintaan dokumen yang terkait dengan dugaan tindak pidana korupsi penyalahgunaan dana BOS SMA N 9 Kota Jambi Tahun Anggaran 2017/2018, dengan ini kami dari pihak sekolah ingin memberikan keterangan terkait dengan permasalahan tersebut.

3) Dengan ini kami beri tahukan bahwa sehubungan adanya terjadi konsleting kabel PLN menuju jalur SMAN 9 Kota Jambi

\section{d. Kesalahan Penulisan pada Paragraf Penutup}

Paragraf penutup digunakan untuk menutup keseluruhan isi surat. Kadang-kadang digunakan untuk menyampaikan kesimpulan, harapan, dan kadang-kadang digunakan untuk menyatakan terima kasih (Semi, 2008: 62). Kesalahan penulisan paragraf penutup surat dinas SMA Negeri 9 Kota Jambi Tahun 2019 sebagai berikut.

1) Demikian disampaikan atas perhatiannya di ucapkan terima kasih.

2) Demikianlah surat keterangan ini kami buat, dan semoga dapat memberikan keterangan agar dapat digunakan sebagaimana mestinya.

3) Demikianlah permohonan ini kami sampaikan, atas kerjasamanya kami ucapkan terima kasih.

Berdasarkan data tersebut diketahui kesalahan penulisan pada kesalahan penulisan pada paragraf penutup surat dinas SMA Negeri 9 Kota Jambi Tahun 2019 sebagai berikut.

1. Kurang cukup penulisan paragraf penutup. Kata demikianlah menyatakan sesuatu yng telah disebutkan sebelumnya, misalnya laporan, penjelasan, keterangan, pemberitahuan. Sebaiknya apa yang telah disebutkan sebelumnya itu dituliskan di belakang kata demikianlah (Soedjito \& Solchan, 2008: 58-59).

2. Pada penulisan di ucapkan yang menggunakan spasi, seharusnya ini tidak perlu diberi spasi. Karena penulisan awalan kata $d i$ yang menyatakan arti suatu pekerjaan atau keadaan penulisannya dirangkai dengan kata yang mengikutinya (Darmawati, 2007: 19).

3. pada penggunaan kata buat yang seharusnya diganti dengan tulis, karena surat merupakan media tulis. Sedangkan kata buat digunakan untuk membuat sesuatu, misalnya membuat makanan, dll.

4. Kurangnya penulisan kata surat sebelum kata permohonan karena jika tidak ditambahkan maka kurang lengkap kalimat tersebut, orang yang membacanya tidak mengetahui lebih detail permohonan apa yang dimaksudkannya.

Sehingga penulisan paragraf penutup yang benar, sebagai berikut.

1) Demikian surat ini disampaikan atas perhatiannya diucapkan terima kasih.

2) Demikianlah surat keterangan ini kami tulis, dan semoga dapat memberikan keterangan agar dapat digunakan sebagaimana mestinya.

3) Demikianlah surat permohonan ini kami sampaikan, atas kerjasamanya kami ucapkan terima kasih.

\section{SIMPULAN}

Berdasarkan hasil analisis kesalahan berbahasa dalam surat dinas SMA Negeri 9 Kota Jambi tahun 2019, maka dapat disimpulkan bahwa masih ditemukan beberapa kesalahan dalam hal- 
hal berikut: (1) penulisan nomor surat, (2) penulisan alamat surat, (3) penulisan paragraf pembuka, dan (4) penulisan paragraf penutup. Selanjutnya bentuk kesalahan berbahasa pada surat dinas SMA Negeri 9 Kota Jambi tahun 2019 adalah sebagai berikut.

Kesalahan penulisan nomor surat yang ditemukan adalah pada tanda baca titik dua dan tanda baca garis miring yang didahului dan dikuti spasi, karena nomor surat tidak perlu diberi spasi.

Kesalahan penulisan alamat surat yang ditemukan adalah kesalahan (1) pada penulisan kata kepada yang tidak perlu ditulis pada kertas surat. Kesalahan (2) pada penggunaan tanda baca titik dua (:) yang seharusnya diganti dengan tanda titik (.), karena tanda baca titik dua (:) dipakai pada akhir suatu pernyataan lengkap yang diikuti pemerincian atau penjelasan). Singkatan Yth. juga seharusnya menggunakan tanda titik bukan dengan tanda titik dua, karena singkatan yang terdiri atas tiga huruf atau lebih diikuti dengan tanda titik. Kesalahan (3) pada penulisan kata diyang tidak perlu ditulis karena nama kota tidak didahului kata depan $d i$, tidak ditulisakan dengan huruf kapital semua, tidak perlu digaris bawahi, dan tidak bertitik akhir atau tanda baca lainnya. Kesalahan (4) pada pengguanaan tanda baca titik (.) diakhir alamat surat yang seharusnya tidak perlu menggunakan tanda titik. Kesalahan (5) pada penggunaan huruf tebal pada alamat surat yang seharusnya ditulis tanpa menggunakan huruf tebal.

Kesalahan penulisan paragraf pembuka yang ditemukan adalah (1) pada penulisan salam pembuka Dengan hormat, diawal paragraf yang seharusnya dimasukkan ke dalam kalimat pertama pembuka surat; (2) pada penulisan dengan ini kami sampaikan bahwa yang seharusnya diganti dengan ini kami beri tahukan bahwa. Karena untuk surat-surat yang berisi suatu pemberitahuan dipergunakan kalimat pembuka Dengan ini kami beri tahukan bahwa.

Kesalahan penulisan paragraf penutup yang ditemukan adalah (1) kurang cukup penulisan paragraf penutup. Kata demikianlah menyatakan sesuatu yang telah disebutkan sebelumnya, misalnya laporan, penjelasan, keterangan, pemberitahuan. Kesalahan (2) pada penulisan kata di ucapkan yang kata depan di menggunakan spasi atau dipisah, seharusnya langsung saja digabung menjadi diucapkan.

\section{Saran}

Saran yang dapat diajukan berdasarkan simpulan di atas adalah sebagai berikut:

1. Bagi penulis surat dinas, penerapan penggunaan kaidah kebahasaan yang baik dan benar harus lebih diperhatikan, sehingga tidak terjadi kesalahan dalam penulisannya.

2. Bagi para guru di sekolah, materi kesalahan berbahasa pada surat dinas ini dapat digunakan sebagai materi tambahan yang diimplementasikan dalam proses pembelajaran.

3. Bagi peneliti, penelitian tentang kesalahan berbahasa dalam penulisan surat perlu lebih diperhatikan, karena sangat berguna dalam proses penyampaian pesan secara tertulis melalui surat dinas atau surat resmi.

\section{DAFTAR PUSTAKA}


Chaer, Abdul. (2006). Tata Bahasa Indonesia. Jakarta: PT Rineka Cipta.

Darmawati, Uti. (2007). Surat Dinas. Klaten: Intan Pariwara.

Keraf, Gorys. (1984). Tata Bahasa Indonesia. Jakarta: Nusa Indah.

Kosasih, Endang. (2012). Dasar-dasar Keterampilan Menulis. Bandung:Yrama Widya.

Mc. Millan \& Sally Schumacher. (2003). Research in Education. Versi terjemahan Sekolah Pascasarjana Program Doktor Ilmu Pendidikan Universitas Islam Nusantara.

Moeliono, Anton M. (1993). Tata Bahasa Baku Bahasa Indonesia. Jakarta: Departemen Pendidikan dan Kebudayaan.

Moleong, Lexy J. (2012). Metodologi Penelitian Kualitatif. Bandung: PT RemajaRosdakarya.

Rahmadi, Duwi. (2017). "Pedoman Umum Ejaan Bahasa Indoneisa \& KesalahanBerbahasa." Solo: Genta Smart Publisher.

Rofii, Afif (2015) An Analysis Of Syntactical Ability Of Second Language Children Age 5-6 Years Old In Taman Kanak-Kanak (TK) Para Bintang Kota Jambi. Jurnal

\section{Ilmiah Dikdaya Universitas Batanghari Jambi.}

Rofii, Afif (2015) Analisis Kesalahan Berbahasa Indonesia dalam Surat Resmi pada Bidang Sintaksis Siswa Kelas VIII Mts N Lubuk Buaya Kota Padang. Jurnal Ilmiah Dikdaya Universitas Batanghari Jambi.Vol. 5, No. 1

Rofii, Afif. dan Hasibuan, Rizka Rani (2019) Interferensi Bahasa Batak Mandailing dalam Tuturan Berbahasa Indonesia Pada Acara Parpunguan Masyarakat Mandailing Kota Jambi. Aksara. Aksara: Jurnal Ilmiah Pendidikan Bahasa dan Sastra Indonesia Vol. 3 No. 1 April 2019

Semi, M. Atar. (2008). Terampil Menulis Surat. Bandung: Titian Ilmu Bandung.

Soedjito \& Solchan. (2013). Surat Menyurat Resmi Bahasa Indonesia. Bandung: PT.Remaja Rosdakarya.

Sugiyono. (2010). Metode Penelitian Kualitatif, Kualitatif dan $R \& D$. Bandung: Alfabeta.

Widjono. Hs. (2015). Bahasa Indonesia. Jakarta: PT Gramedia. 